\title{
Parechovirus Genotype 3 Outbreak Among Young Infants in Portugal
}

\author{
Surto de Infeção em Portugal por Parechovirus \\ Genótipo 3 em Pequenos Lactentes
}

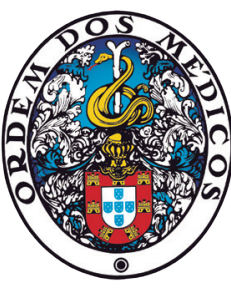

\author{
Maria Inês LINHARES $\otimes^{1}$, Ana BRETT ${ }^{1,2}$, Lurdes CORREIA ${ }^{3}$, Henriqueta PEREIRA ${ }^{3}$, Cristina CORREIA ${ }^{4}$, \\ Mónica OLEASTRO ${ }^{4}$, Rita de SOUSA ${ }^{4}$, Fernanda RODRIGUES ${ }^{1,2}$ \\ Acta Med Port 2021 Oct;34(10):664-668 - https://doi.org/10.20344/amp.15032
}

\section{ABSTRACT}

Introduction: Human parechovirus type 3 has been recognized as a cause of pediatric infection, occasionally associated with serious illness, including sepsis and meningitis, particularly among young infants. The aim of this study is to report the first known human parechovirus type 3 outbreak in Portugal.

Material and Methods: Descriptive study of an outbreak that occurred from the $8^{\text {th }}$ June to the $12^{\text {th }}$ August 2016. Laboratory diagnosis was made by reverse transcription - polymerase chain reaction in the cerebrospinal fluid and/or in stools. Genotyping was made by reverse transcription - polymerase chain reaction and sequencing in stool samples from infants and family members.

Results: Human parechovirus type 3 infection was detected in seven infants, of which six were male. Median age was 23 days (5 - 52). One had seizures, with a magnetic resonance imaging scan showing white matter diffusion restriction. The mean duration of admission was 5.6 days $(3-11)$, with favourable outcome in all. In three cases there were symptomatic close family members. Human parechovirus type 3 was identified in the stools of three mothers.

Discussion: Even though human parechovirus type 3 infection has been well described in the presented age group, most Portuguese hospitals do not have this laboratory diagnosis. Our results are comparable to those obtained in other countries. Besides detection of the virus in the cerebrospinal fluid, there were no raised local or systemic inflammatory markers.

Conclusion: This study reports the first known outbreak, in infants, of human parechovirus type 3 in Portugal. Although there is no specific treatment, this diagnosis can avoid unnecessary empirical antibiotic treatment and prolonged admissions.

Keywords: Communicable Diseases, Emerging; Infant; Parechovirus; Picornaviridae Infections; Portugal

\section{RESUMO}

Introdução: O parechovirus humano tipo 3 tem sido reconhecido como causa de infeção em idade pediátrica, ocasionalmente associado a doença grave, incluindo sépsis e meningite, particularmente em pequenos lactentes. Foi objectivo deste estudo descrever o primeiro surto conhecido de infeção por parechovirus humano tipo 3 em Portugal.

Material e Métodos: Estudo descritivo de um surto ocorrido entre 8 de junho a 12 de agosto de 2016. O diagnóstico laboratorial foi realizado por transcriptase reversa - reação em cadeia da polimerase no líquido cefalorraquidiano e/ou nas fezes. A genotipagem foi efetuada no Instituto Nacional de Saúde Doutor Ricardo Jorge, por transcriptase reversa - reação em cadeia da polimerase e sequenciação, em amostras de fezes dos lactentes e seus familiares.

Resultados: Foi detetada infeção por parechovirus humano tipo 3 em sete lactentes, seis dos quais do sexo masculino, mediana de idade de 23 dias (5 - 52). Uma lactente apresentou convulsões, com múltiplas lesões da substância branca na ressonância magnética nuclear. A duração média de internamento foi de 5,6 dias (3 - 11), com evolução favorável em todos. Em três casos havia familiares próximos sintomáticos. Em três mães foi identificado parechovirus humano tipo 3 nas fezes.

Discussão: Embora a infeção por parechovirus humano tipo 3 esteja bem descrita neste grupo etário, a maior parte dos hospitais portugueses não dispõe deste diagnóstico laboratorial. Os resultados obtidos foram semelhantes aos verificados noutros países. Apesar da deteção do vírus no líquido cefalorraquidiano, destaca-se a ausência de resposta inflamatória local ou sistémica.

Conclusão: Este estudo reporta o primeiro surto conhecido de infeção por parechovirus humano tipo 3 ocorrido em Portugal em pequenos lactentes. Apesar de não existir tratamento específico, este diagnóstico poderá evitar poderá evitar antibioterapia e internamentos prolongados.

Palavras-chave: Doenças Transmissíveis Emergentes; Infecções por Picornaviridae; Lactentes; Parechovirus; Portugal

\section{INTRODUCTION}

The human parechoviruses (HPeVs) are non-enveloped single stranded RNA viruses within the Picornaviridae family. Currently, HPeVs are classified into 19 genotypes based on genetic variation. ${ }^{1} \mathrm{HPeV}$ s have been recognized as a cause of infection in children, usually characterized by mild gastrointestinal and respiratory symptoms. However, severe conditions such as sepsis-like syndrome, and/ or central nervous system (CNS) involvement have been associated with genotype 3 infection in young infants and neonates. ${ }^{2,3}$

Human parechovirus type 3 (HPeV-3) infections have been described as single cases, small series of sporadic unrelated infections and outbreaks. ${ }^{4-8}$ Identifying HPeVs as the causative agent of infection may be helpful in guiding

1. Serviço de Urgência e Unidade de Infecciologia. Hospital Pediátrico. Centro Hospitalar e Universitário de Coimbra. Coimbra. Portugal.

2. Clínica Universitária de Pediatria. Faculdade de Medicina. Universidade de Coimbra. Coimbra. Portugal.

3. Serviço de Patologia Clínica. Centro Hospitalar e Universitário de Coimbra. Coimbra. Portugal.

4. Departamento de Doenças Infecciosas. Instituto Nacional de Saúde Dr. Ricardo Jorge. Lisboa. Portugal.

$\triangle$ Autor correspondente: Maria Inês Linhares. inesrclinhares@gmail.com

Recebido: 10 de abril de 2020 - Aceite: 07 de dezembro de 2020 - First published: 15 de março de 2021 - Online issue published: 01 de outubro de 2021 Copyright @ Ordem dos Médicos 2021 
treatment decisions and follow-up. The incidence of HPeV infections in Portugal is unknown, since it is not a notifiable disease.

We report the first known outbreak in Portugal of HPeV3 in infants.

\section{MATERIAL AND METHODS \\ Study design}

Ethics committee approval was not considered necessary since this was a retrospective, non-interventional study, and all data was anonymised. All the procedures were done according to the regulations established by the National Ethics Committee for Clinical Research and to the principles established by the Helsinki Declaration of the World Medical Association updated in 2013.

\section{Outbreak investigation}

Infant patients were admitted to the Emergency Department of a tertiary children's hospital - Hospital Pediátrico in Coimbra - from June to August 2016, with a clinical diagnosis of fever without a source. Demographic, clinical and laboratory data were collected based on the patient records.

\section{Laboratory diagnosis}

Molecular HPeV detection was performed in patient's cerebrospinal fluid (CSF) specimens using a real-time multiplex polymerase chain reaction (PCR) commercial kit (Biofire ${ }^{\circledR}$ Filmarray ${ }^{\circledR}$ Meningitis/Encephalitis Panel) according to the manufacturer's instructions. Stool samples were sent to the reference laboratory at the National Institute of Health Dr. Ricardo Jorge, where characterization of the HPeV type was performed. RNA was extracted from both infant and maternal stools using automatic extraction Nuclisens EasyMag system (bioMérieux), according to the manufacturer's instructions. Genotyping was performed by conventional one-step reverse transcription PCR (Rt-PCR) based on sequencing partial fragments of the capsid viral protein 1 (VP1) gene, as previously described by Benschop et al. ${ }^{9}$

\section{Epidemiological investigation}

An epidemiological survey, including information regarding the presence of respiratory, gastrointestinal and cutaneous symptoms in any member of the household in the past 14 days, was applied in all the cases. Maternal stool samples were obtained. The hospital's infection control team and the Public Health Unit of the Regional Health Administration of the Central region of Portugal analyzed, through an epidemiological survey, if transmission could have occurred within the hospital.

\section{Follow-up}

Post-discharge assessments were carried out according to clinical presentation and severity of the condition.

\section{RESULTS}

Between the $8^{\text {th }}$ June and $12^{\text {th }}$ August 2016, HPeV infection was confirmed in seven young infants hospitalized in

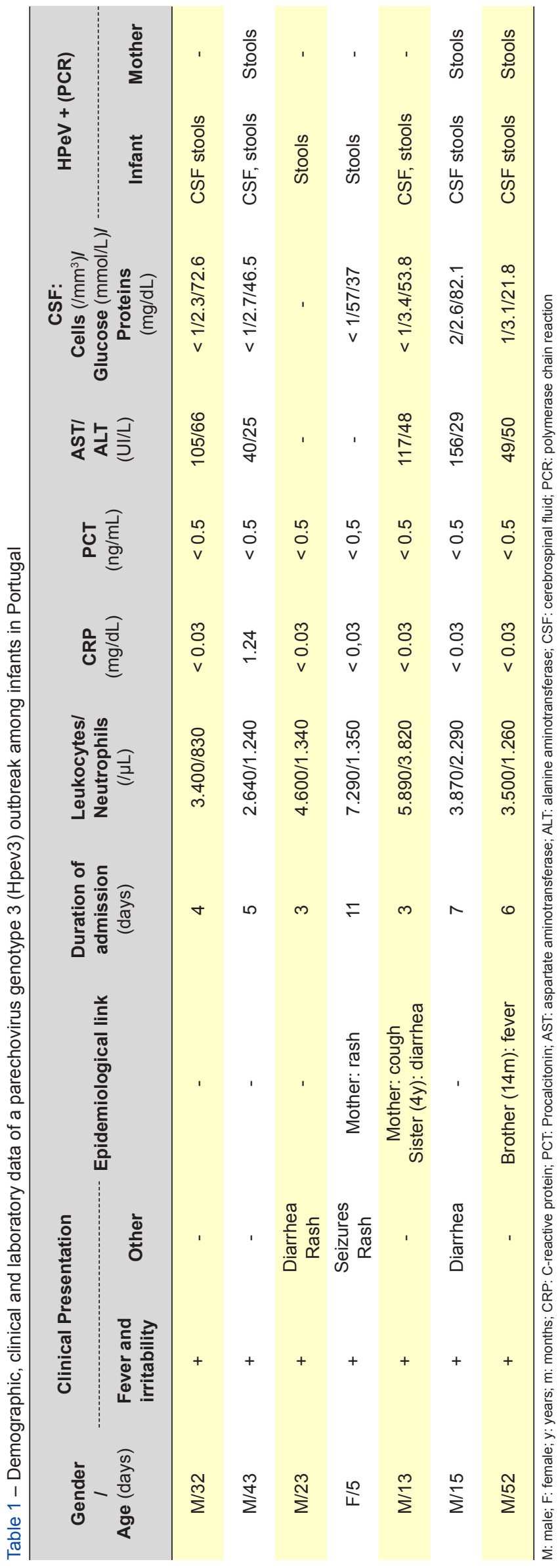


Hospital Pediátrico, in Coimbra.

Demographic, clinical and laboratory characteristics are shown in Table 1.

Median age was 23 days (5 - 52), six were boys. All of them presented with fever (axillary temperature $\geq 38^{\circ} \mathrm{C}$ ) and irritability, two with gastrointestinal symptoms, and two with a rash with involvement of the distal extremities. The only girl developed fever on the fifth day of life and seizures the following day, with magnetic resonance imaging (MRI) showing white matter diffusion restriction. All children underwent head ultrasound, that showed no abnormalities. Three cases had symptomatic close family members with fever, rash, respiratory and/or gastrointestinal symptoms, one week before or at the same time as the cases.

Regarding hospital laboratory investigation at admission, leukopenia was identified in five infants, and none had significant elevation of C-reactive protein (CRP) or procalcitonin (PCT). There was elevation of liver enzymes (AST and/or ALT) in three cases. Lumbar puncture (LP) was performed in six cases: there was no pleocytosis, and glucose and protein levels were within normal limits. LP was not performed in one case due to the benign clinical presentation and progression. Blood and CSF cultures were all negative. In the six CSF specimens tested by multiplex PCR, five were positive for $\mathrm{HPeV}$. The stools of the negative case were nevertheless tested as there was suspicion of a possible outbreak. Molecular characterization, done in stool samples, identified genotype 3 in all the cases, and in three asymptomatic mothers.

Empirical intravenous antibiotics were started in six infants, until negative culture results were obtained. Fever persisted between two and four days. Mean duration of hospital stay was 5.6 days, with favorable outcome in all.

All children were born in the same maternity hospital, but the epidemiological survey applied by the hospital infection control team and the Public Health Unit of the Regional Health Administration of the Central region of Portugal concluded there was no known evidence of nosocomial transmission. No other epidemiological link was found, with all families living in different geographical areas and with no contact between them.

Regular follow-up in the neurology clinic (every six months) occurred only in the case with CNS involvement, until three years of age. In the remaining cases, follow-up was done in the infectious disease's clinic during the first two months and subsequently by their family physicians. None of the infants developed apparent neurodevelopmental complications, including the female infant with encephalitis, who, at the age of three, had an appropriate psychomotor development, including a MRI showing no abnormalities.

In our hospital, after this outbreak, only two more cases were diagnosed, in August 2018 and in October 2019.

\section{DISCUSSION}

Despite several outbreaks reported worldwide, ${ }^{4-8}$ the incidence of HPeV infection is not well known and is likely underestimated. ${ }^{3}$ This study reports the first outbreak in Portugal of HPeV-3 In infants.

As in our case series, others have reported increased detection of HPeV-3 infections in late spring and summer. ${ }^{4-7}$ Despite this, and similar to enterovirus infections, HPeV can cause illness at any time, highlighting the importance of testing for these viruses throughout the year., ${ }^{3,6,7}$

In our study, most patients were male, which is similar to other previous reports. ${ }^{4,6,8}$ All infants were aged under three months and four were neonates, as in other studies. ${ }^{4-8}$ Seropositivity for $\mathrm{HPeV}$ type 1 (HPeV-1) is almost universal in adults, whereas in a Dutch study only $10 \%$ of adults carried HPeV-3 antibodies. ${ }^{10}$ This low seroprevalence can explain this age distribution by low maternal-derived antibodies against HPeV-3, 2,10,11 which can also justify infection in mothers. On the other hand, LPs are more frequently performed in younger infants with fever without a source, and therefore interpretation can be biased. A longitudinal study of 102 Norwegian infants, in which stool samples were tested, detected $\mathrm{HPeV}$ at least once in $43 \%$ of children before 12 months of age and in $86 \%$ before 24 months of age: HPeV-1 was detected most frequently, but types three and six were also found. ${ }^{12}$

The most likely reported source of infection is usually an older, asymptomatic sibling. ${ }^{11}$ Close contact with the siblings, combined with a lack of maternal antibodies against HPeV-3, might increase the susceptibility to infection in small infants. In this series, there were two symptomatic siblings as well as two mothers. Transmission can occur through the fecal-oral route from both asymptomatic and symptomatic infected individuals, in whom viral loads have been shown to be similar. The estimated median duration of shedding in stool is over 50 days. ${ }^{12,13}$ There is not much data available regarding transmission through the respiratory tract, which has been suggested to be a possible acquisition route in children with CNS symptoms. ${ }^{14}$ Respiratory shedding is estimated to have a duration of one to three weeks. ${ }^{13}$ Little is known about other epidemiological links, but according to some authors, HPeV in surface waters could also pose a risk for children and other vulnerable populations. ${ }^{15}$ In the present outbreak, no water source was analyzed. Although the incubation period for $\mathrm{HPeV}$ is difficult to determine, the observed intervals between infection and appearance of symptoms seem to be between one to 12 days. ${ }^{6}$ In our study, most cases became symptomatic after 12 days of life, showing that, although all were born in the same maternity hospital, the infection may have been acquired outside the hospital, which is in agreement with the results of the epidemiological survey that was applied.

All cases presented with fever without a source and irritability, similar to previous reports. ${ }^{4-8}$ In a large Australian series of HPeV-3 infection, ${ }^{4}$ more than $93 \%$ of 118 infants presented with fever and irritability. Additionally, most infants presented a widespread macular, and often erythrodermic, rash. These 'red, hot, angry babies' allowed for rapid and accurate identification of infected infants during this outbreak. In our case series, two cases had a 
maculo-papular rash with involvement of the distal extremities, including palms and soles. Our description is similar to that of another study where the appearance of a 'gloves and socks' rash was reported in $80 \%$ of infants infected with $\mathrm{HPeV}-3$, with onset between the first and the fifth day of fever and with an average duration of three days. ${ }^{16}$

Despite the presence of fever, we did not find raised inflammatory markers, which is in line with other studies, ${ }^{4-8}$ with all cases having CRP levels below $1.5 \mathrm{mg} / \mathrm{dL}$ and negative procalcitonin levels. Leukopenia was present in most cases. The absence of CSF pleocytosis, as well as normal CSF glucose and protein levels, has also been consistently demonstrated. ${ }^{4,5,7,8}$ Although neonatal sepsis did not occur in our case series, it is the most common severe clinical manifestation of HPeV-3 infection, and is known to be associated with increased vascular permeability and reduced blood-brain barrier function. Viremia and increased bloodbrain-barrier permeability may allow passive virus leakage into the CNS. ${ }^{17}$ Therefore, detection of HPeV-3 RNA in CSF samples may not be a sign of active virus replication in the CNS but rather a consequence of a systemic inflammatory response. However, it has also been shown that HPeV-3 is capable of infecting neuronal cell lines, suggesting neural tropism, ${ }^{18}$ which could potentially lead to meningitis and encephalitis, as seen in the female infant.

Molecular detection by PCR is considered the diagnostic test of choice for viral detection. ${ }^{2,3}$ Currently, only a limited number of Portuguese hospitals have this test available. In our study, HPeV-3 was detected in five of the six CSF specimens tested and in all stool samples. In the Australian outbreak, ${ }^{4}$ up to $36 \%$ of cases were diagnosed from noninvasive samples, such as stool, nasopharyngeal aspirate, rectal or throat swab.

To date, no antiviral drugs have been approved for the treatment of picornavirus infections and treatment is limited to supportive care..$^{2,3}$ A study from The Netherlands ${ }^{18}$ showed that intravenous immunoglobulin (IVIG) and specific antibodies efficiently neutralized HPeV-1 in vitro, while most HPeV-3 strains could not be neutralized. Considerable variability in the levels of HPeV-neutralizing antibodies present in different IVIG preparations may explain this finding, as this study found extremely low neutralizing antibody titers in IVIG preparations and in the serum of HPeV3-infected donors. However, a study from Japan reported high HPeV-3-neutralizing antibody titers in six different IVIG preparations, ${ }^{19}$ probably related to a much higher HPeV-3 seroprevalence in Japanese adults. ${ }^{20}$ Further clinical trials would be needed before IVIG could be recommended for routine treatment of HPeV infections. In our case series, intravenous antibiotic therapy was started and maintained until exclusion of bacterial infection by culture, despite the PCR result. This might be due to the fact that these were the first cases in which HPeV was detected in our hospital, and there was insufficient confidence in the predicted value of the test to discontinue antibiotics.

A favorable outcome was observed in all infants, and no intensive life-support was required. The female infant aged five days at admission was the only case that presented with encephalitis, with white matter and diffusion changes in the MRI. In a prospective study carried out in five Australian tertiary hospitals, ${ }^{21}$ nine cases of HPeV-3 encephalitis were confirmed between May 2013 and December 2014, with a mean age of 13 days and a majority of female infants; this suggests early age as a risk factor for encephalitis, as well as greater susceptibility for females All cases identified in the Australian study showed changes in the white matter in the MRI. However, no changes in the cranial ultrasound were found, suggesting that the latter examination is not very sensitive and does not exclude encephalitis. In the same study, neurological sequelae were identified in five cases: two with cerebral palsy, one with central vision impairment and the remaining two with delayed motor development. In our series, all cranial ultrasounds were normal and no sequelae were detected in post-discharge assessments. Further studies are needed to define the risk and severity of long-term complications.

\section{CONCLUSION}

This study reports the first outbreak in Portugal of HPeV3 in infants and the first cases diagnosed in this hospital, where molecular diagnosis is available since 2014. Despite the detection of the virus in the CSF, there were no raised local or systemic inflammatory markers. All children were born in the same maternity hospital, but no common source of infection was identified. Although there is no specific treatment, diagnosis helped to reduce antimicrobial use and shorten hospital stay.

\section{AUTHORS CONTRIBUTION}

MIL: Analysis and interpretation of data, draft of the manuscript.

$A B, F R$ : Conception of the study, analysis of the results, draft of the manuscript.

LC, HP: Laboratory analysis, review of the manuscript.

CC: Participation in molecular diagnosis and typing.

MO: Participation in molecular diagnosis and typing, critical review of the manuscript.

$\mathrm{RS}$ : Analysis of the results, critical review of the manuscript.

\section{PROTECTION OF HUMANS AND ANIMALS}

The authors declare that the procedures were followed according to the regulations established by the Clinical Research and Ethics Committee and to the 2013 Helsinki Declaration of the World Medical Association.

\section{DATA CONFIDENTIALITY}

The authors declare having followed the protocols in use at their working center regarding patients' data publication.

\section{COMPETING INTERESTS}

The authors have declared that no competing interests exist regarding the publication of this paper. 


\section{FUNDING SOURCES}

This research received no specific grant from any funding agency in the public, commercial, or not-for-profit sectors.

\section{REFERENCES}

1. Picornaviridae.com [homepage na Internet]. UK: The Pirbright Institute, c2006-20. [accessed 2020 feb 2]. Available from: https://www. picornaviridae.com/parechovirus/parechovirus_a/parechovirus_a.htm.

2. Olijve L, Jennings L, Walls T. Human parechovirus: an increasingly recognized cause of sepsis-like illness in young infants. Clin Microbiol Rev. 2018:31:e00047-17.

3. Crom SC, Rossen JW, Van Furth AM, Obihara CC. Enterovirus and parechovirus infection in children: a brief overview. Eur J Pediatr. 2016;175:1023-9.

4. Khatami A, McMullan BJ, Webber M, Stewart P, Francis S, Timmers KJ, et al. Sepsis-like disease in infants due to human parechovirus type 3 during an outbreak in Australia. Clin Infect Dis. 2015;60:228-36.

5. Ferreras Antolín L, Kadambari S, Braccio S, Tang JW, Xerry J, Allen DJ, et al. Increased detection of human parechovirus infection in infants in England during 2016: epidemiology and clinical characteristics. Arch Dis Child. 2018;103:1061-6.

6. Strenger V, Diedrich S, Boettcher S, Richter S, Maritschnegg P, Gangl $D$, et al. Nosocomial outbreak of Parechovirus 3 infection among newborns, Austria, 2014. Emerg Infect Dis. 2016;22:1631-4

7. Cabrerizo M, Trallero G, Pena MJ, Cilla A, Megias G, Muñoz-Almagro $\mathrm{C}$, et al. Comparison of epidemiology and clinical characteristics of infections by human parechovirus vs those by enterovirus during the first month of life. Eur J Pediatr. 2015;174:1511-6.

8. Valle F, Calvo C, Rienda I, Cilla A, Romero M, Menasalvas AI, et al. Características epidemiológicas y clínicas de los lactantes hospitalizados por infecciones por parechovirus humanos. Estudio prospectivo en España. An Pediatr. 2018;88:82-8.

9. Cremer J, Morley U, Pas S, Wolthers K, Vennema H, Duizer E, et al Highly sensitive parechovirus CODEHOP PCR amplification of the complete VP1 gene for typing directly from clinical specimens and correct typing based on phylogenetic clustering. J Med Microbiol. 2019;68:1194-203.

10. Westerhuis B, Kolehmainen P, Benschop K, Nurminen N, Koen G, Koskiniemi M, et al. Human parechovirus seroprevalence in Finland and The Netherlands. J Clin Virol. 2013;58:211-5.
11. Aizawa Y, Yamanaka T, Watanabe K, Oishi T, Saitoh A. Asymptomatic children might transmit human parechovirus type 3 to neonates and young infants. J Clin Virol. 2015;70:105-8.

12. Tapia G, Cinek O, Witso E, Kulich M, Rasmussen T, Grinde B, et al. Longitudinal observation of parechovirus in stool samples from Norwegian infants. J Med Virol. 2008;80:1835-42.

13. Wildenbeest JG, Benschop KS, Bouma-de Jongh S, Wolthers KC Pajkrt D. Prolonged shedding of human parechovirus in feces of young children after symptomatic infection. Pediatr Infect Dis J. 2016;35:5803.

14. Sharp J, Bell J, Harrison CJ, Nix WA, Oberste MS, Selvarangan R. Human parechovirus in respiratory specimens from children in Kansas City, Missouri. J Clin Microbiol. 2012;50:4111-3.

15. Lodder WJ, Schijven JF, Rutjes SA, Husman AM, Teunis PF. Entero and parechovirus distributions in surface water and probabilities of exposure to these viruses during water recreation. Water Res. 2015;75:25-32.

16. Shoji K, Komuro H, Miyata I, Miyairi I, Saitoh A. Dermatologic manifestations of human parechovirus type 3 infection in neonates and infants. Pediatr Infect Dis J. 2013;32:233-6.

17. Danielski LG, Giustina AD, Badawy M, Barichello T, Quevedo J, DalPizzol F, et al. Brain barrier breakdown as a cause and consequence of neuroinflammation in sepsis. Mol. Neurobiol. 2018;55:1045-53.

18. Westerhuis BM, Koen G, Wildenbeest JG, Pajkrt D, de Jong MD, Benschop KS, et al. Specific cell tropism and neutralization of human parechovirus types 1 and 3: implications for pathogenesis and therapy development. J Gen Virol. 2012;93:2363-70.

19. Aizawa $Y$, Watanabe $K$, Oishi T, Hirano H, Hasegawa I, Saitoh A. Role of maternal antibodies in infants with severe diseases related to human parechovirus type 3. Emerg Infect Dis. 2015;21:1966-72.

20. Tanaka S, Aoki Y, Matoba Y, Yahagi K, Itagaki T, Matsuzaki Y, et al. Seroepidemiology of human parechovirus types 1, 3, and 6 in Yamagata, Japan, in 2014. Microbiol Immunol. 2016;60:854-8.

21. Britton PN, Dale RC, Nissen MD, Crawford N, Elliott E, Macartney K, et al. Parechovirus encephalitis and neurodevelopmental outcomes. Pediatrics. 2016;137:20152848. 